\title{
Preliminary Reflection on Performance Indicator and Performance Factor for Infrastructure Asset Management
}

\author{
Hitapriya Suprayitno ${ }^{1, \mathrm{a})}$, Ria Asih Aryani Soemitro ${ }^{1, \mathrm{~b})}$, Mahendra Andiek Maulana ${ }^{1, \mathrm{c})}$ \\ \& Yervi Hesna ${ }^{2, d)}$ \\ ${ }^{1)}$ Civil Engineering Department, Institut Teknologi Sepuluh Nopember (ITS), Surabaya, Indonesia. \\ ${ }^{2)}$ Civil Engineering Department, Universitas Andalas, Padang, Indonesia. \\ Corespondance : ${ }^{\text {a) }}$ suprayitno.hita@gmail.com, ${ }^{\text {b) }}$ ria@ce.its.ac.id, ${ }^{\mathrm{c}}$ mahendrasipil@gmail.com \& \\ d)yervi2005@gmail.com.
}

\begin{abstract}
Performance Evaluation is routine work for IAM. Related to this, the Performance Indicator and Performance Factor need to be well understood. This paper presents the result of a preliminary reflection on infrastructure performance, performance indicators, and performance factors. Basic Quality of infrastructure is measure by its Performance to execute its Function. Performance Factor is something that can influence the performance. Performance may consist of several components. Each Performance components indicate different qualities. Each performance component may have different importance levels and different values. The factor may consist of several factors. Each factor has its nature as supporting or resisting performance. Each factor has its strength of influence, its easiness to be manipulated, and its value.
\end{abstract}

Keywords : infrastructure asset management, performance indicator, performance factor.

\section{INTRODUCTION}

In Indonesia nowadays, Infrastructure and Facility Asset Management become an obligation for Public Infrastructure. Infrastructure and Facility Management is knowledge, sciences, and practices to Manage Infrastructure and Facility along its life span. During this life span, infrastructure evaluation must be executed periodically to assess the infrastructure condition or the infrastructure quality (PP 27/14; Soemitro \& Suprayitno 2018; Suprayitno \& Soemitro 2018; UU 1/04).

Infrastructure needs to be well managed. Thus, it needs to be well operated, well maintained, well constructed, well designed, well planned, well registered, well disposed of. Operation and maintenance must be based on infrastructure conditions or infrastructure performance. Infrastructure Management needs an infrastructure program based on good infrastructure evaluation (Suprayitno \& Soemitro 2018).

From the Infrastructure Asset Management point of view, the Basic Quality of infrastructure is measured based on its Performance to execute its Function (Suprayitno \& Soemitro 2108; Suprayitno \& Soemitro 2019a). Performance may not single, it can be several, and it must indicate something which is part of infrastructure operation quality.

Certain management techniques: Importance Performance Analysis, Strategic Management, Highest Solution Reduction by Needs and Constraints (HSRNC), Factor Analysis, Principal Component Analysis, Explanatory Factor Analysis, Confirmatory Factor Analysis, and the others seem needed in Infrastructure Asset Management (Abdurachman 2004; Balasundaram 2009; Hoyle 2004; Mishra et al 2017; Sammut-Bonici 2014; Suprayitno \& Tangahu 2018; William, Onsman, \& Brown 2010; Wong, Hideki \& George 2011; Yong \& Pearce 2013). All of these techniques need formulation of Performance Indicator and 
Performance Factor. Thus, a systematic understanding of performance indicators and performance factor needs to be developed.

In a lot of cases, it has been found that defining the performance indicator and performance factor sometimes is not easy at all. People still can be confused and do not have a clear understanding of these. Thus systematic knowledge on Performance Indicators and Performance Factors needs to be developed.

This paper presents the result of an attempt to develop a preliminary understanding of the performance indicator and performance factor for Infrastructure Asset Management.

\section{RESEARCH METHOD}

The research has been executed by following these steps: background statement, objective formulation, concept development, and finished by conclusions. The concept development followed these reflection steps: a general understanding of performance, basic view of public infrastructure, basic view of infrastructure operation, observed infrastructure, performance indicator, performance factor, a method to define the performance indicator and performance factor, synthesis.

\section{CONCEPT DEVELOPMENT}

\section{General Understanding of Performance}

Two very simplified examples are written below, to show the signification of Performance, Performance Indicator, Performance Factor, and several other related concepts. Two cases were used, i.e. a diabetic patient in-hospital treatment and a $100 \mathrm{~m}$ sprinter in training to improve his timing. The twos simplified cases are presented below.

A diabetic person, by chance, has a blood sugar level of 500 . He needs to be treated in a hospital, to reduce and to stabilize his blood sugar level. Diabetic is a problem of the pancreas cannot produce insulin normally as needed by the blood. As a consequence, the sugar level in the blood cannot be controlled by the body itself. The too high blood sugar level is not good. The hospital treatment is about to control the blood sugar level, by controlling carbohydrate intake and by adding the insulin if needed. The Treatment Performance is about whether the blood sugar level can be decreased and be stabilized step by step. Factors that can influence the Treatment Performance are various. Positive Factors are medicine to increase blood insulin content and fruits. The Negative Factors are soft drink and meat consumption. Consuming medicine will increase blood insulin content. Eating a lot of fruits will reduce the blood sugar content. But, drink a lot of soft drinks will increase the blood sugar content, eat a lot of red meat will increase the cholesterol thus the sugar content also a little bit. The strength of the medicine as a factor to influence is stronger than fruit as a factor. While soft drink give a stronger impact than red meat. Besides these all, there is a genetic factor that tends to weaken the pancreas to produce insulin. This genetic factor is a permanent factor that cannot be manipulated.

A $100 \mathrm{~m}$ sprinter athlete is in a training program to improve his running quality. The training Performance Indicator is of course his Sprint Time, which needs to be reduced step by step. His Performance Factor can be identified as a physical condition, training quality, food diet, alcohol consumption, daily life rhythm. The Supporting Factor is the training quality and food diet. The Resisting Factor is alcohol consumption. The Supporting-Resisting Factor is the daily life rhythm and physical condition. Different factor has different Influence Strength. Factors having a strong influence are training quality, daily life rhythm, alcohol consumption, and physical condition. Factors having a weak influence are food diet quality. Factors can be easy or hard to be manipulated. Factors easy to be manipulated are training and food diet, these can be programmed easily to be in good training and a good diet. Factors impossible to be manipulated is physical anatomy measure. 
The two simplified samples above can indicate easily that Performance is influenced by Performance Factors. Factors have value. These can be of supporting or resisting factor, can be of strong or weak factor, can be easily manipulated or permanent.

\section{Basic View of Public Infrastructure for Infrastructure Asset Management}

Professional dealing with Infrastructure Management is still dominated by the Infrastructure Engineer. Meanwhile, Infrastructure Management is not Infrastructure Engineering. Thus the Infrastructure Manager must know well the other view of infrastructure which is not Infrastructure Engineering. It has been formulated that the Basic View of infrastructure for Infrastructure Manager should consist of infrastructure system, general infrastructure physical aspects, infrastructure function, infrastructure supply-demand, infrastructure operation, infrastructure maintenance, infrastructure register, infrastructure disposal, infrastructure economy, etc (Suprayitno \& Soemitro 2019).

\section{Basic View of Infrastructure Operation}

From the point of view of Infrastructure Asset Management, the Basic Quality of Infrastructure is measured based on its Performance to execute its Functions. The Infrastructure Performance is of course influenced by its Physical Condition, its Operation Characteristics, and its Operation Management. Operation Management involves Operation Performance Measure (Suprayitno \& Soemitro 2019a). This principle is presented as Diagram in Figure 1 below.

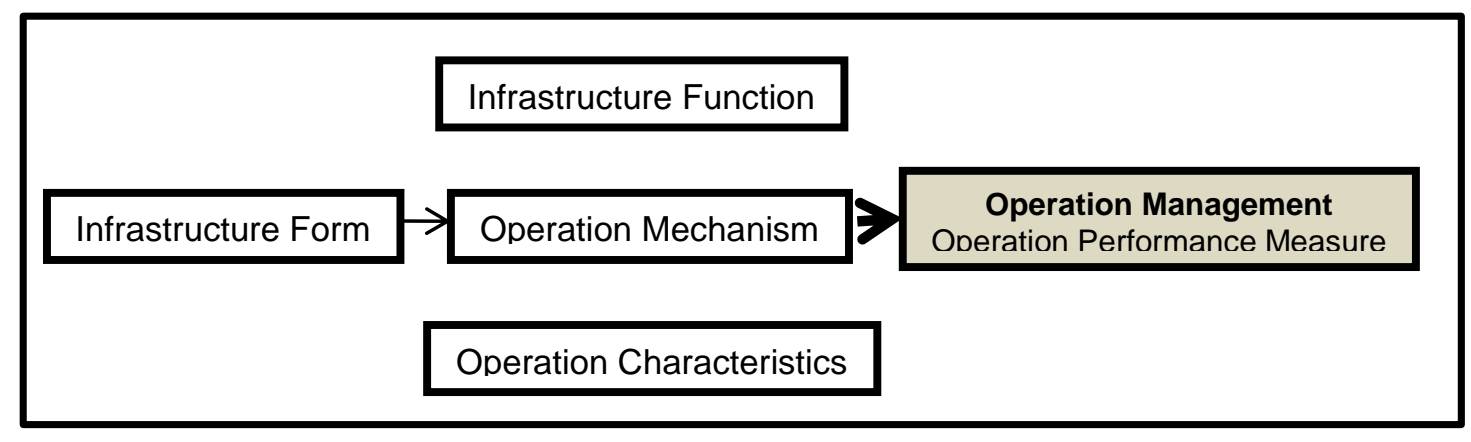

Figure 1. Infrastructure Operation Management Diagram

\section{Observed Infrastructures}

For developing the understanding of performance indicators and the performance factor, 4 infrastructures, taken from 4 groups of Public Works Infrastructure, were taken as Observed Infrastructures. They are an irrigation network, road network, water supply installation, and low cost public rental public apartment. These 4 infrastructures are presented below.

The irrigation network consists of the intake, primary ditch, secondary ditches, feeder ditches, and distribution boxes. The function is to irrigate water to different rice fields as a program: a certain amount of water quantity at a certain period. An example of the Irrigation Network is presented in Figure 2 below. 


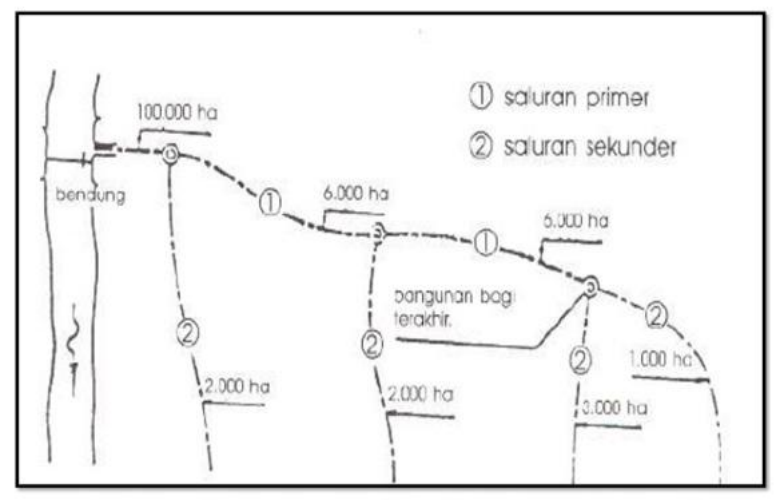

Figure 2. Irrigation Network Scheme

The road network consists of the whole network in a certain region. It can be seen, the road segment is classified into several classes. The main function of the road is to connect different nodes and to flow the traffic. An example of a road network is presented in Figure 3 below.

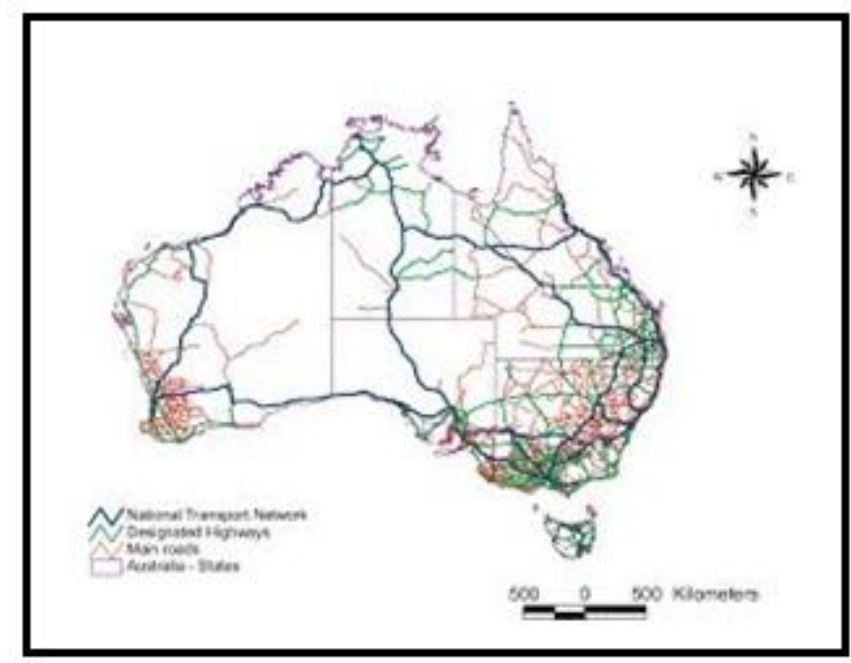

Figure 3. Road Networkl

The Water Supply Installation consists of the intake, water purification installation, water tower, and distribution pipeline. The main function of the installation is to take water from a river, to purify the water into clean water, and to distribute the water to different clients in the serving area. An example of Water Supply Installation is presented in Figure 4 below.

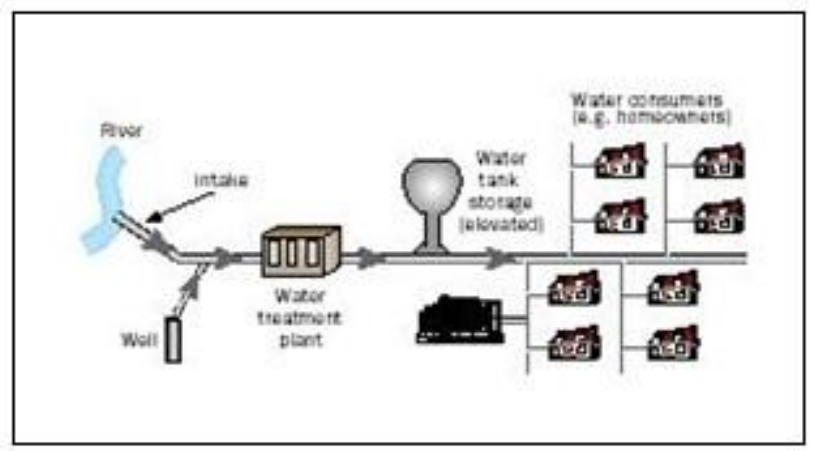

Figure 4. Water Supply Network 
The Public Low-Cost Rental Apartment, normally, consists of several apartment buildings in a land lot. The main function of the apartment is to be resided by a low economic population because they are not capable of purchasing a house for themselves. An example of the Public Low-Cost Rental Apartment is presented in Figure 5 below.

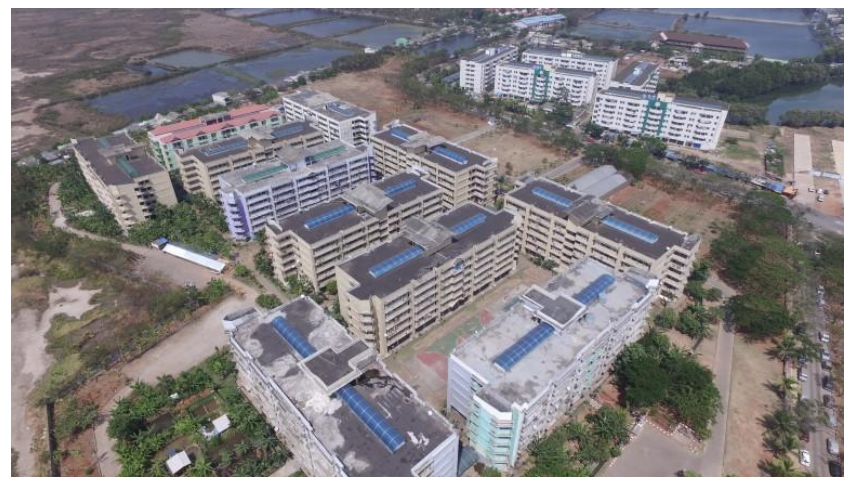

Figure 5. Low-Cost Public Rental Apartment

\section{Performance Indicator}

Definition

Each infrastructure has one or several formulations of functions. Each function has one or more performance formulations. Therefore, an infrastructure practically has several performance components, in which each performance has its performance indicator. Each Performance Indicator has its own Performance Value and Performance Importance. Performance Value is the value of the Infrastructure Operation Performance. Performance Importance is the level of importance the performance indicator has. Different Performance Indicators may have different Levels of Importance. The most important indicator has to be considered in the first place. The Performance Indicator Diagram is illustrated in Figure 2 below.

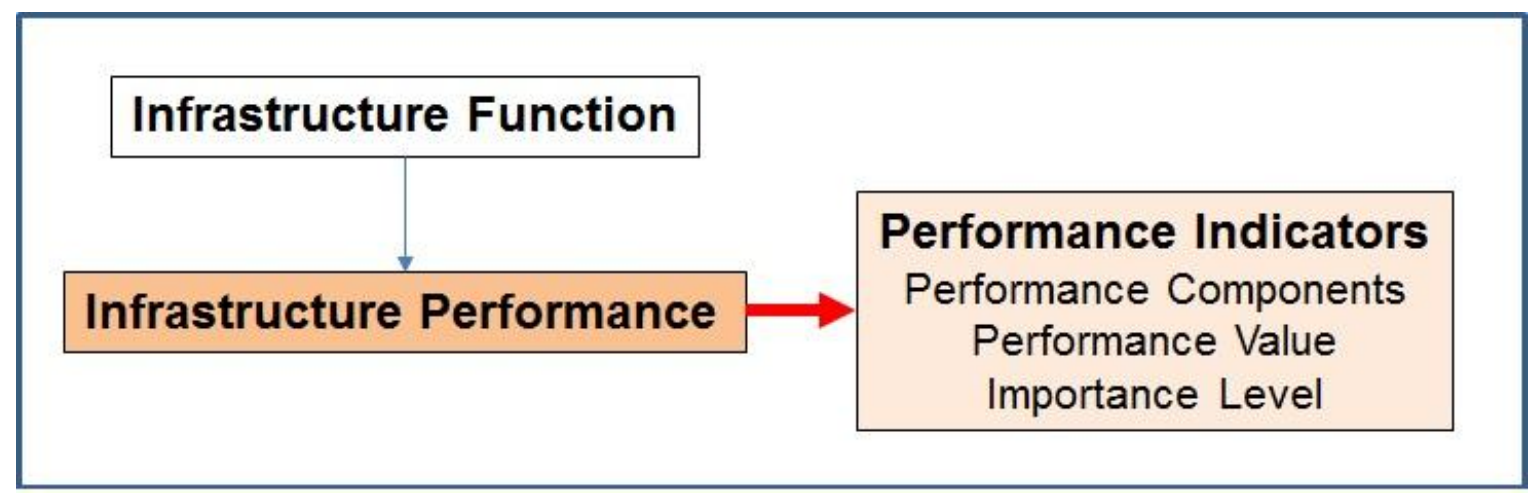

Figure 6. Performance Indicator Diagram

\section{$\underline{\text { Reflection on Infrastructure Performance Indicator }}$}

As examples, a reflection of Performance Indicators is formulated based on function, for the four observed infrastructures. The Performance Indicators are presented in Table 1 below. 
Table 1. Example of Performance Indicator

\begin{tabular}{|l|l|l|}
\hline Infras tructure & Function & Performance Indicator \\
\hline \multirow{3}{*}{ Irrigation Network } & to distrbute the water to different ditch & water volume dis tributed \\
\cline { 2 - 3 } & to distrbute the water to different rice field & water volume dis tributed \\
\hline \multirow{3}{*}{ Road Network } & to connect nodes & number of nodes connected \\
\cline { 2 - 3 } & to flow traffic & fluidity of flow \\
\hline \multirow{3}{*}{ Water Installation } & to clean water & the water quality \\
\cline { 2 - 3 } & to distribute & quantity \& quality \\
\hline \multirow{3}{*}{ Public Rental Appartment } & to be resided by the renter & number of occupancy \\
\cline { 2 - 3 } & electricity & always on \\
\cline { 2 - 3 } & water & always avaliable \\
\cline { 2 - 3 } & sanitation & always in function \\
\hline
\end{tabular}

\section{Performance Factor}

\section{Definition}

Performance Factor is something that has a capacity to influence the Infrastructure Performance, either towards good performance or bad performance. Different factor has a different strength of influence and easiness to be manipulated. The performance factor can be of inner or outer factor, supporting or resistance factor, and its value. The Performance Factor Diagram is presented in Figure 7 below.

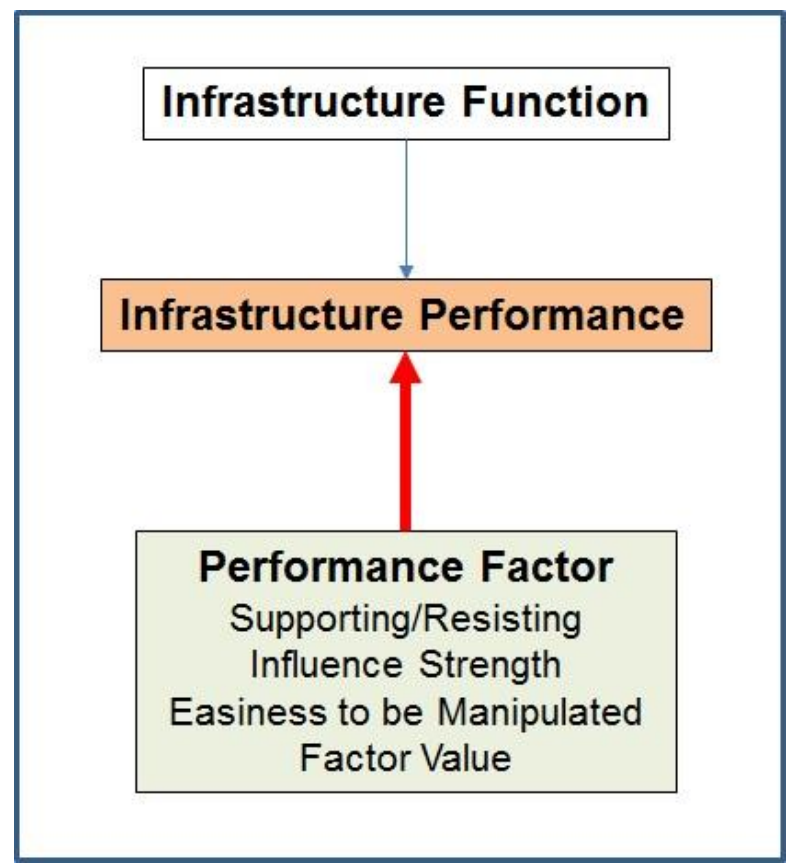

Figure 7. Diagram of Performance Factor

\section{$\underline{\text { Reflection on Infrastructure Performance Factor }}$}

A reflection on the Infrastructure Performance Factor has been developed. The preliminary reflection is presented in Table 2 below. 
Table 2. Infrastructure Performance Factor

\begin{tabular}{|l|l|l|}
\hline Infras tructure & Pe rformance & Factor \\
\hline \multirow{2}{*}{ Irrigation Network } & \multirow{2}{*}{ the quantity of water dis tributed } & water intake debit \\
\cline { 3 - 3 } & & quality of dis tribution box \\
\hline \multirow{2}{*}{ Road Network } & pourcentage of connected node & road network extent \\
\cline { 3 - 3 } & & road clas sification \\
\hline \multirow{2}{*}{ Water Supply System } & adequacy of water distribution & intake water quality \\
\cline { 3 - 3 } & & water treatment condition \\
\hline \multirow{2}{*}{ Public Rental Appartment } & residence load factor & apartment physical condition \\
\cline { 3 - 3 } & & electricity condition \\
\hline
\end{tabular}

\section{Method to Define the Performance Indicator and Performance Factor}

Defining the Performance Components, the Performance Factors and its attribute values (importance, supporting/resisting, influence strength, easiness to be manipulated, value) can be done by several principals, from the most simple to the most refined. These methods, listing from the very basic to the most refined is presented below.

- by using their own reflection

- by using the own reflection refined by using literature review

- by using own reflection refined by asking the expert

- by using refined statistical analysis - factor analysis/principal component analysis.

\section{Synthese}

The whole performance indicator and performance factor concepts above can be synthesized in a diagram presented in Figure 8, Figure 9, and Figure 10 below.

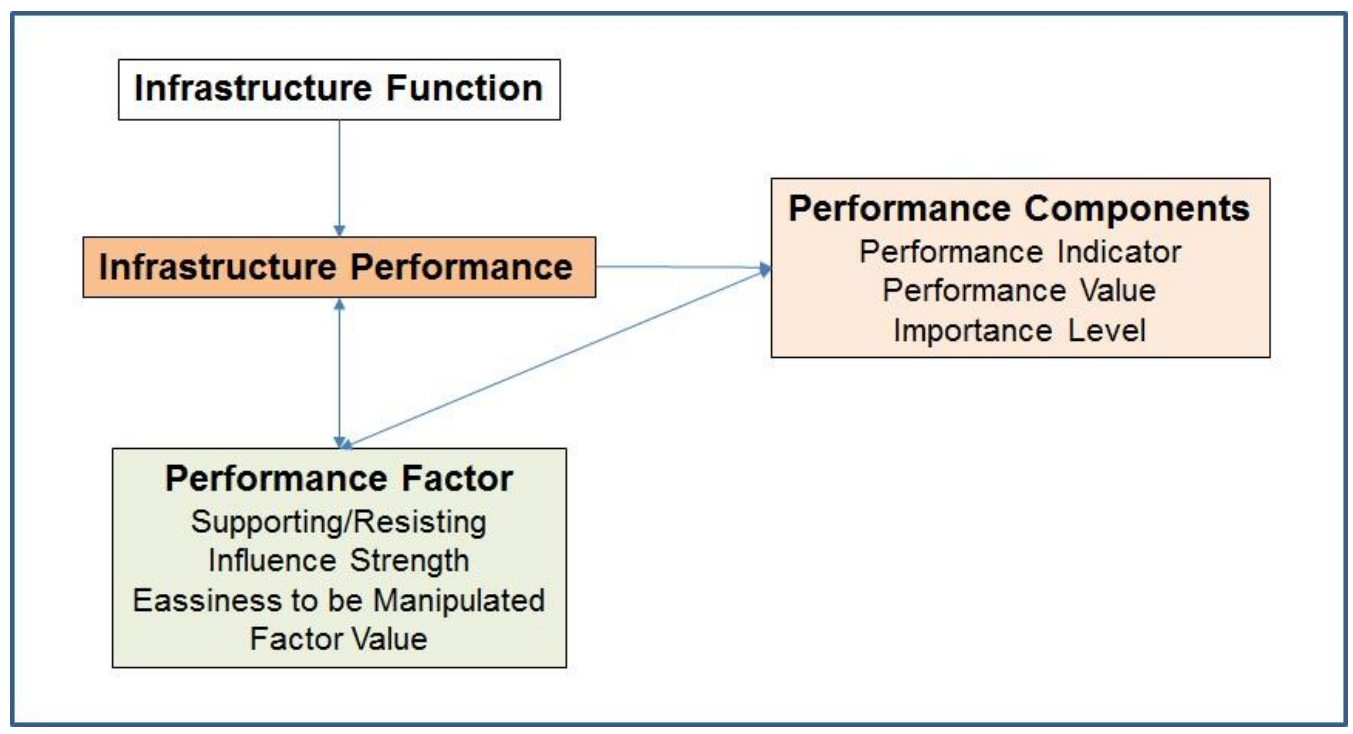

Figure 8. Performance Indicator and Performance Factor Diagram 


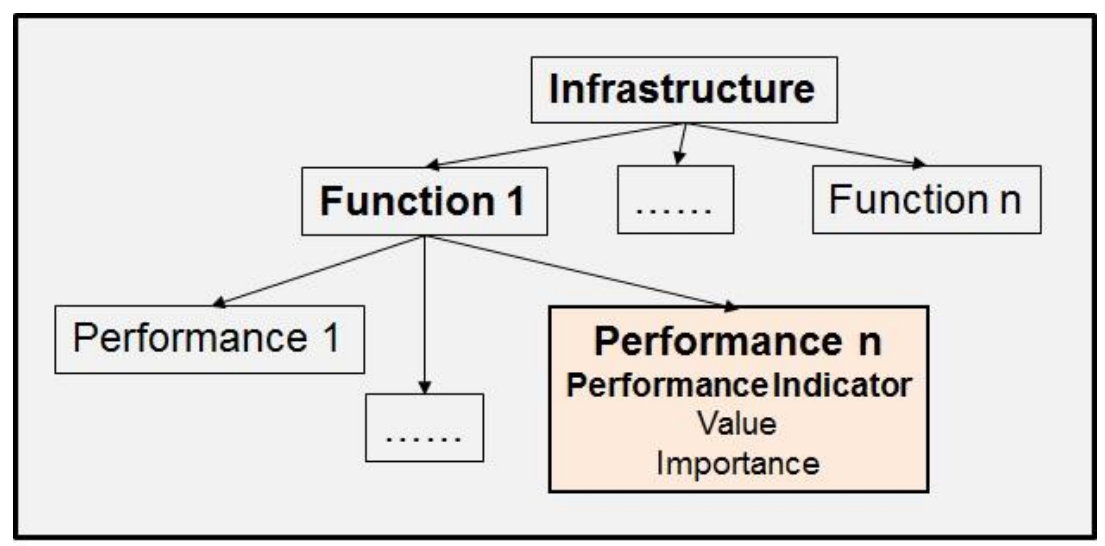

Figure 9. Performance Indicator Diagram

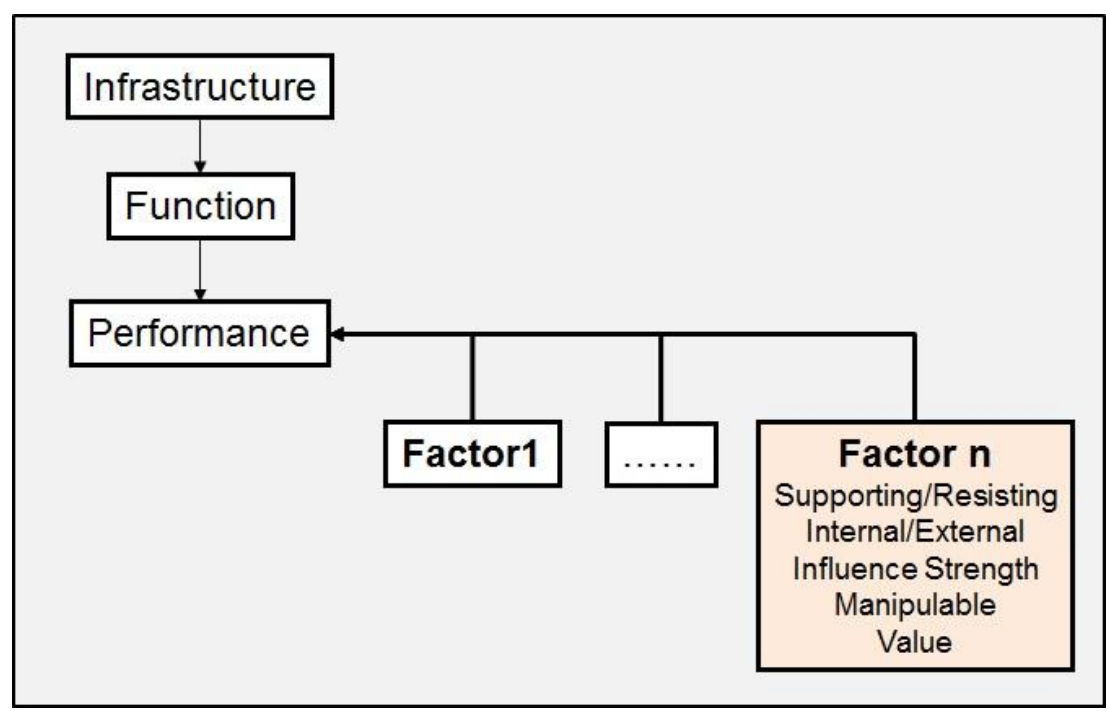

Figure 10. Performance Factor Diagram

\section{CONCLUSIONS} as below.

As the research has been finished, several main conclusions can be formulated and written

- The Infrastructure Basic Quality is formulated as its Performance to Execute its Functions.

- The Performance consists of one or several components with its Importance Level and its Value. These are called Performance Indicators

- A factor is something capable of influencing the Performance Value. These can of inner or outer factors.

- The factor may consist of several factors, whether supporting or resisting factor, its influence strength, its easiness to be manipulated, and its value.

- The values should be measured in a numeric value, either nominal or cardinal.

After finishing this reflection, further curiosities were induced, i.e. try to formulate performance for different infrastructures, try to identify the performance factors, try to develop a systematic method to designate the performance indicator, try to develop a systematic method to produce performance factor, reflection on the way to test whether the measurement tools are correct. 
Notes. This paper was written for ACE 6 2019. The objective of this paper is to participate in developing I\&FAM knowledge. The I\&F Performance is an important part of I\&FAM, but paper covering this matter is still rare.

\section{REFERENCES}

Abdurachman, Ujianto (2004). “Analisis Faktor-Faktor yang menimbulkan Kecenderungan Minat Beli Konsumen Sarung (Studi Perilaku Konsumen Sarung di Jawa Timur)". Jurnal Manajemen dan Kewirausahaan, Vol. 6, No. 1, Maret 2004, Hal. : 34-53.

Balasundaram (2009). "Factor Analysis: Nature, Mechanism and Uses in Natural and Management Science Research". Journal of Cost and Management Accountant, Bangladesh 2009, XXXVII (2): 15-25.

Hoyle, R.H. (2004). Confirmatory Factor Analysis. In M. Lewis Back, A. Bryman, \& T. Liao (Eds.). Encyclopedia of Social Science Research Methods (Vol. 1, pp. 169-175), Thousand Oaks, CA: Sage Publications.

Mishra, S.P., Sarkar U., Tarapdher, S., Datta, S., Swain, D.P., Saikhom, R., Panda, S., \& Laishram, M. (2017). "Multivariate Statistical Data Analysis - Principal Component Analysis". International Journal of Livestock Research, Vol. 7 (5), May 2017.

PP 27/14. Peraturan Pemerintah Republik Indonesia Nomor 27 Tahun 2014 tentang Pengelolaan Barang Milik Negara/Daerah.

Sammut-Bonici, T. (2014). Strategic Management. In Wiley Encyclopedia of Management, edited by Prof. Sir Cary L. Cooper, Copyright (C) 2014 John Wiley \& Sons, Ltd.

Suprayitno, H. (2014). Metoda Penilaian Kualitas Jaringan Jalan Utama di Wilayah Kabupaten. Disertasi RC 09-3399. Jurusan Teknik Sipil. Institut Teknologi Sepuluh Nopember (ITS). Surabaya.

Suprayitno, H. \& Soemitro, R.A.A. (2018). "Preliminary Reflexion on Basic Principle of Infrastructure Asset Management". Jurnal Manajemen Aset Infrastruktur \& Fasilitas, Vol. 2, No. 1, Maret 2018.

Suprayitno, H. \& Soemitro, R.A.A. (2019). "Reflection on Basic View of Public Infrastructure for Infrastructure Asset Management in Indonesia". Jurnal Manajemen Aset Infrastruktur \& Fasilitas, Vol. 3, Suplemen 1, Juni 2019.

Suprayitno, H. \& Soemitro, R.A.A. (2019a). "Preliminary Reflection on Basic Principle of Operation Management for Public Work Infrastructure Asset Management". Presented in SENIMA 4 - Seminar Nasional Manajemen 4, Surabaya, 5 Oktober 2019. Universitas Negeri Surabaya. Surabaya.

Suprayitno, H. \& Tangahu, B.V. (2018). "Formulating a Policy for Developing Regional Solid Waste Final Disposal Installation in East Java Province". Jurnal Manajemen Aset Infrastruktur \& Fasilitas, Vol. 2, Suplemen 1, Juni 2018.

UU 1/04. Undang-Undang Republik Indonesia Nomor 1 Tahun 2004 tentang Perbendaharaan Negara.

Williams, B., Onsman, A. \& Brown, T. (2010). "Exploratory Factor Analysis: A Five-Step Guide for Novices". Journal of Emergency Primary Health Care (JEPHC), Vol. 8, Issue 3, 2010 - Article 990399.

Wong, M.S., Hideki, N. \& George, P. (2011). "The Use of Importance Performance Analysis in Evaluating Japan's E-Government Services”. Journal of Theoretical and Applied Electronic Commerce Research, Vol. 6, Issue 2, August 2011, 17-30.

Yong, A.G. \& Pearce, S. (2013). “A Beginner's Guide to Factor Analysis: Focusing on Exploratory Factor Analysis". Tutorials in Quantitative Methods for Psychology, Vol. 9 (2), 2013, p. 79-94. 
(e)ISSN 2656-8896 (p)ISSN 2656-890X

Journal of Infrastructure and Facility Asset Management - Vol. 2, Issue. 1, March 2020 